Acta Universitatis Wratislaviensis No 3836

Anglica Wratislaviensia LVI, Wrocław 2018

DOI: 10.19195/0301-7966.56.18

\author{
Anna Dudek \\ ORCID: 0000-0003-1160-8954 \\ University of Wrocław \\ anna.dudek.uwr@gmail.com
}

\title{
The Untranslatability of Dialects in Subtitling. An Analysis of Translation Techniques Used in the English Subtitles to The Peasants*
}

\begin{abstract}
The aim of this research is to estimate the degree of dialect untranslatability in audiovisual translation (AVT). Polish regiolects may constitute a significant barrier to interlingual transfer. The problems with non-standard varieties of a language, which are frequently incomprehensible even to native speakers of their standard counterparts, can be overcome by means of, inter alia, explanatory periphrastic substitution added to the translated text. In the method of subtitling examined in this research, however, a translation of this kind is nearly impossible due to the broadly defined aesthetics of film (e.g. time and space constraints frequently applied to the mode of AVT). Therefore, this article examines the hypothesis of dual constraint, which assumes a two-fold hindrance to a successful AV dialect transfer (i.e. the lack of equivalents in the target language and the aforementioned aesthetic requirements of film). The corpus of the material researched here is based on the English subtitles for the screen adaptation of Chłopi - a Nobel Prize-winning novel written by Władysław Stanisław Reymont (The Peasants; PolArt Video 2006). This article provides the theoretical background for the subsequent study as well as introduces its own classification of the translation techniques (applicable to this particular piece of research as well as to other AV dialect transfers). The research part focuses on the research proper. The findings are briefly summarised and conclusions are drawn.
\end{abstract}

Keywords: untranslatability, dialect, audiovisual translation (AVT), subtitling, The Peasants, Władysław Stanisław Reymont

\section{Introduction}

It can be reasonably stated that the development of translation studies today is directly proportional to the growth of interlingual communication. Gradually extending

* This article is based on the author's MA thesis entitled "The Untranslatability of Dialects into the Language Used in Films: An Analysis of Translation Techniques Used in the English Subtitles to The Peasants," written under supervision of dr hab. Marek Kuźniak, Assistant Professor at the University of Wrocław. 
to "the whole range of human knowledge" (Newmark 1991: 16), translating has long since ceased to be "a simple communicative act" (Venuti 2000: 468). For many years, various scholars have been making Herculean attempts to establish a comprehensive theoretical framework for the notion of translation. Nevertheless, due to its immense complexity, it is frequently argued that one needs an intuitive perception of the concept of translation rather than a scholarly one (Wojtasiewicz 1992 [1957]: 11-13). Newmark elaborates on this, saying that a "good" translation, despite its intricacy, "is not difficult to identify" (Newmark 1991: 34). Unfortunately, as Jull Costa observes: "A cloud of negativity tends to hover over the subject of translation. People say sourly that something 'reads like a translation' [...]" (Jull Costa 2007: 111). This tendency may be directly connected to the notion of untranslatability. As suggested by many theoreticians, untranslatability falls into two categories: either the target language (TL) lacks source language (SL) structures or the phenomena of the source culture (SC) are inconceivable in the TL (Wojtasiewicz 1992 [1957]: 28; Catford 1965: 100). The phenomenon of "absolute untranslatability" is also a matter of dispute. For instance, Bałuk-Ulewiczowa states that untranslatability results from significant SL and TL discrepancies regarded as "extra-textual emotional experience" or, in other words, cultural differences (Bałuk-Ulewiczowa 2000: 173-174). Nida agrees, saying that "the differences between cultures cause many more severe complications for the translator than do differences in language structure" (Nida 2000 [1964]: 130). Nevertheless, Wojtasiewicz states reassuringly that: "We know from practice that the translation process is in principle feasible. The untranslatability relates only to some peculiarities, which may even be quite numerous, but can be interpreted as exceptions from the general principle of translatability from one language to another"1 (Wojtasiewicz 1992 [1957]: 28). Nonetheless, it may be reasonably stated that the level of untranslatability may be directly related to the level of linguistic complexity. In this regard, non-standard varieties of a given language may result in a higher number of untranslatable passages. Such a translation requires the application of specific procedures which are, inter alia, additional explanations added in the form of footnotes. In the $21^{\text {st }}$ century, however, translation modes have come into existence in which no explanatory translation technique can be applied, for instance audiovisual translation (AVT) modes, including voice-over, dubbing, and the mode of subtitling discussed in this article.

The aim of the paper is to examine the quality of subtitling in The Peasants - a film based on the 1901-1908 novel of the same title written by Władysław Stanisław Reymont (Chłopi; dir. Jan Rybkowski, Telewizja Polska S.A. 1973; translated by Agata Deka, PolArt Video 2006). The choice of this particular film was determined by at least two conditions decisive for its distinctive character. First and foremost, the language used throughout the film is not the standard variety of the Polish language. The rustic variety used by Władysław Stanisław Reymont

\footnotetext{
${ }^{1}$ All translations, if not otherwise stated, are mine: A.D.
} 
is actually a juxtaposition of several non-standard historical variations of Polish which overlap throughout the text, aiming at evoking the very special feeling of a $19^{\text {th }}$ century Polish village and its scenery. The following part of this article discusses the key concepts necessary for the research, which are: dialect (understood as a non-standard variety of a given language); translator (including the issue of socalled translator's competence); and AVT (with special regard to the mode of subtitling). Subsequently, this article proposes its own division into three groups of translation techniques, which may find their application in the course of translating non-standard language varieties in AVT. In this part, the article outlines the dual constraint hypothesis, which aims to confirm the assumption that non-standard varieties cannot be translated properly in $\mathrm{AV}$ products without the loss of the rustic sounding vocabulary and grammatical structures. In order to examine how the suggested set of translation techniques works in practice, the research part analyses 20 dialogue lines taken from the film being examined. The findings verify the dual constraint hypothesis in regard to the research part and attempt at providing conclusions concerning the accuracy of the research.

\section{The concepts of dialect and translator's responsibility in AVT}

Defining the notion of language variation is widely considered to be a challenging task. Dialect is frequently referred to as a gradually evolving language variety, extending to the "provincial, uncultivated, uneducated, and even stupid" social strata (Chambers \& Trudgill 2004 [1998]: 3-5, 102; Francis 1987 [1983]: 9, among others). It is worth noticing that a rustic variation, "mindlessly accepted within the SL," may generate a considerable "cultural shock in the TL" (Newmark 1991: 75). For centuries, dialects have been used in various forms of artistic expression. The use of non-standard varieties was acknowledged in the literature of, for instance, Geoffrey Chaucer, William Shakespeare, and Charles Dickens. Linguistic variety in literature may serve various functions. As observed by Pinto, it provides a cultural outline of the speaker together with his/her position in the fictional context, which results in the aforementioned social stratification. Pinto also noted that "the literary use of a dialect in literary texts seems to be a particularly good example of that balancing of meaning and prioritization of elements. Not only because of its very localised meaning (both in time and space), but also because it is always embedded in the source text with a communicative and semiotic significance" (Pinto 2009: 289). What is more, the author of the original text frequently aims at creating the so-called "fictional orality" effect (defined by Brumme and Espunya as "any attempt to recreate the language of communicative immediacy in fictional texts, including both narrative and theatrical texts as well as audiovisual or multimodal texts;" Brumme \& Espunya 2012: 13). 
The issue of semiotic and pragmatic difficulties constitutes one of the major obstacles in translating literary dialects, which stems from the "close relationship between the speaker, the medium and the context in which it is used and consequently evokes and explores extra-linguistic knowledge" (Pinto 2017: 2-5). Finally, the method of recreating (or not recreating) a given language variation may, according to Pinto, "modify, or even subvert, the work's internal coherence" (Pinto 2009: 290-291; 2017: 2-5). This statement concerning the way a translator constructs his product refers directly to the next issue, namely the issue of a translator's competence.

The translator, viewed as a privileged reader, writer and critic (Patterson 2006 qtd. in Jull Costa 2007: 113; Kuhwiczak 2003: 114), should — by means of his "uncommon ability" in writing in his native language - try to reproduce the original effect, yet remaining an invisible servant of the source text's (ST) "truth" (Newmark 1991: 40; Lefevere 1992: 38; Venuti 1995; Kizeweter 2012: 444). In order to meet all these requirements, the translator is obliged to possess a special set of qualities which make him/her a good translator; these qualities are generally referred to as "translator's competence" (Rothe-Neves 2007:126). Eser notes that this refers to "various skills and knowledge that a translator needs to have in order to translate functionally" (Eser 2015: 4). However, the translator is exposed to some kind of temptation. As Kizeweter observes, "the process of equalling [the ST author: A.D.] can easily take in the characteristics of solicitation" (Kizeweter 2012: 436). The responsible translator, then, is obliged to minimise his "wilfulness," striving to transfer the "truth" from the ST to the target text (TT) as accurately as possible. Last but not least, the translator should be mindful of the other decisive factor in a successful translation, i.e. the audience. As the receivers decide whether to reject or accept a translation product, the transfer "must be so clear that no one can possibly misunderstand" (Nida 2000 [1964]: 128; cf. Hejwowski 2015). Audience feedback is especially important when it comes to modern types of artistic expression, for instance the mode of AVT which is the focus of this paper.

Despite its growing popularity in recent times, the mode of AVT only became an academic focus as recently as in the 1980s (Gambier 2003: 182). Discussing this mode, one has to underscore its peculiar character. According to Tomaszkiewicz, AV meaning results from the mutual relations between "written and spoken linguistic elements, still and moving pictures, sounds, and music" and this co-existence should be taken into account while preparing the TT (Tomaszkiewicz 2006: 102). In a broad sense, the main reason for the peculiarity of AVT is the so-called aesthetic dimension. The constrained nature of the subtitling discussed in this research (resulting from the method of displaying the translated text on the screen simultaneously with the picture) requires extortionate TT condensation. On the one hand, the text calls for an immediate understanding, on the other hand - all the transcribed dialogue lines should not blur the message sent via another significant element of the multimodal complex, which is the picture. The translator, then, is obliged to provide an accurate and condensed translation product. This notion, hereinafter referred to as "film 
aesthetics," is one of the most problematic issues in AVT. Pinto observes that "given the multimodal nature of the AV product, the choice of not portraying non-standard features could be motivated by the assumption that the visual mode will provide viewers with similar information" (Pinto 2016: 7). Despite the above observation, one has to note that there are no established, clear-cut criteria for a successful AV dialect translation. This may result from the "pressure of censorship," which frequently imposes the use of a high level standard variety of the language and the fact that the translation of foreign linguistic varieties into native ones may not be well received by the TT readership (Pinto 2009: 301; Brodovich 1997). What is more, as Pinto observes, "in the case of subtitling, where the source and target texts appear simultaneously, translators can never escape the fact that there may be people in the audience who understand the source language" (Pinto 2009: 302). This issue led to the creation of "a class of privileged viewers who have greater control over how to use the translation, as they are able to compare the original dialogue with the subtitled version in their own or other languages [...]" (Díaz-Cintas 2003: 198).

Finally, it should be emphasised that the language used in The Peasants is even more cumbersome, as the AV text is not constructed in the style of contemporary substandard varieties. The novel of the same title, on which the film is based, was written in 1901-1908. Consequently, the dialects overlapping throughout the film are historical rather than contemporary ones. Consequently, both the grammatical and lexical structures used in The Peasants may not be comprehensible even for contemporary Polish viewers. What is more, there are no established criteria for the AVT of historical dialect. Therefore, the next section of this article aims at providing a set of translation tools applicable to the research that follows, dividing both AV and literary translation techniques into three groups.

\section{The applied research method and the dual constraint hypothesis}

As mentioned earlier, despite the great diversity of literature on the subject of translation techniques, little has been said on the methods relevant to translating AV dialect ${ }^{2}$. In order to accommodate the theory to the needs of the present study, this article provides its own division into three general approaches which may be applicable to AV dialect translation:

${ }^{2}$ Among the theoreticians dealing with AV dialect translation one may mention Díaz-Cintas and Cruz and their considerations concerning the use of subtitling in the classroom environment (Díaz-Cintas \& Cruz 2008: 206-207) as well as Toda, who notes that one "cannot really 'translate' an accent or use a target-language dialect expression in subtitle" (Toda 2008: 166). Nevertheless, despite sporadic remarks and scientific references, the topic of interlinguistic rustic expressions remains hardly discussed and, to the author's knowledge, no classification of AV dialect translation techniques has been provided so far. 
Translation techniques aimed at explaining non-standard lexical items. The most popular techniques in this regard are those which aim at supplementing the TT with additional information (Hejwowski 2006: 82-83; Newmark 1988: 83; Tomaszkiewicz 2006: 167, among others). This solution, however, cannot be used excessively in the present debate due to AVT space constraints. What is more, scholars underscore the AV technique of picture reference, which supplements the translation product with a "meaningful" picture displayed on the screen (Belczyk 2007: 27-31). Finally, one has to mention the neutralisation technique allowing for a thorough "intralingual and interlingual ST translation" (Berezowski 1997: 88-89).

Translation techniques aimed at TT reduction. Unquestionably, one of the most widespread techniques in this respect is omission. This method, "cutting out" the problematic lexical items, is generally considered to be "the most radical solution" in the translation process (Tomaszkiewicz 2006: 155-167; Belczyk 2007: 27-31). There are also numerous "grammar-simplifying approaches" at hand, shortening the TT yet conveying the very essence of the ST message (Belczyk 2007: 27-31), as well as the widespread technique of adaptation, assimilating the foreign receiver with the translated text and thus allowing for its immediate comprehension (Tomaszkiewicz 2006: 167; Newmark 1991: 3). It should be emphasised that these techniques are frequently used in subtitling - not only in the cases in which a non-standard variety is involved.

Translation techniques aimed at producing the effect of foreignness. One may reasonably state that the renowned strategies of domestication and foreignisation (Schleiermacher 1813; Venuti 1995) constitute the cornerstone of translation theory. The former strategy "leaves the reader in peace as much as possible" and "moves the author towards him," whereas the latter operates in the opposite direction, leaving the TT receiver with a hint of strangeness (Schleiermacher 1813 qtd. in Lefevere 1977: 74). Nevertheless, it should be emphasised that these approaches do not constitute strictly separated opposing camps, as their juxtaposition is also widely acknowledged in the literature. It is sufficient to mention the foreignisation through domestication translation strategy, which, by means of applying domesticating tools, results in increasing the level of strangeness in the TT. This extraordinary effect may occur either purposefully or as an unintentional product. Lefevere believes that the translator's excessive knowledge may occasionally "backfire" on him, leading to the construction of a highly foreignised TT (Lefevere 1992: 5). Furthermore, a misinformed translator may also construct a "strangeness-evoking" TT passage. Nevertheless, as far as the mode under discussion is concerned, Díaz-Cintas states that the aforementioned strategies are "clearly insufficient when dealing with AVT," and that "their re-elaboration is necessary" (Díaz-Cintas 2004: 29). Finally, many theoreticians advocate the method of replacing a rustic ST variation with another one: a merger of two TL varieties (Morini 2006: 124); a synthetically created TL (cf. Brett 2009: 51); a corresponding geographical TL equivalent (Lebiedziński 1981 in Berezowski 1997: 33); or a colloquial variety of the TL 
(Berezowski 1997: 88-89). Those techniques aim at reflecting a "hint of village scenery" in translation. As Pinto notes, there is an assumption that any "recreation of linguistic varieties in the subtitles contributes to a more accurate interpretation and cognisation" (Pinto 2016: 12).

To summarise the above, one may state that dialects (i.e., the highly specific variations connected to the regional SC with multifarious bounds), and the AVT mode (demanding a clear and concise ST transfer) are in contradiction to each other. Consequently, this article makes use of the previously mentioned dual constraint hypothesis, which draws on the following two assumptions:

1. A non-standard SL variation is untranslatable due to the lack of a corresponding non-standard TL variation.

2. A non-standard SL variation is untranslatable due to the film aesthetics discussed above.

Taking this hypothesis into account, it may be claimed that the non-standard varieties of a language simply cannot be translated into the film language without losing their peculiar sound. Regardless of the method applied - be it an elaborative technique, reduction, or a "foreigness-evoking" approach - the AV translation product fails at reconstructing the ST structure. Consequently, the subsequent study illustrates the majority of the abovementioned translation approaches in practice, focusing on examples that confirm or challenge the hypothesis being discussed. The research part consists of an analysis of 20 dialectically marked lexical items. All of the examples are taken from the subtitled version of The Peasants (Chtopi; dir. Jan Rybkowski, Telewizja Polska S.A. 1973; translated by Agata Deka, PolArt Video 2006). The Polish instances are based on the ST dialogue list, whereas the English examples - on the TT subtitled version. The examined lexical items are written in bold.

\section{Research}

4.1. Translation techniques aimed at explaining non-standard lexical items Table 1 shows examples of translations of dialectical expressions by means of an explanatory periphrastic substitution:

Table 1: Explanatory periphrastic substitution

\begin{tabular}{|l|l|l|}
\hline No. & \multicolumn{1}{|c|}{ Polish } & \multicolumn{1}{|c|}{ English } \\
\hline 1. & $\begin{array}{l}\text { Maciej: Na wycug do ciebie nie pójdę, } \\
\text { nie! }\end{array}$ & $\begin{array}{l}\text { Maciej: I won’t turn over the land to you } \\
\text { and be in your keep. Never! }\end{array}$ \\
\hline 2. & Piotr: Bo też Jagna jak rzepa! & Piotr: She is a strong girl. \\
\hline
\end{tabular}


It may be stated that both examples above, despite their condensed TT structure, were translated in a way which allows the receiver to understand the text immediately. Nevertheless, the sound of the ST is irretrievably lost. The picture reference technique is used in the next two examples:

Table 2: Picture reference

\begin{tabular}{|l|l|l|}
\hline No. & \multicolumn{1}{|c|}{ Polish } & \multicolumn{1}{c|}{ English } \\
\hline 3. & Villager: Stroi się jak na odpust! & Villager: Decked out like for a church fair. \\
\hline 4. & Jagna: A to jest na jarmarku? & Jagna: Is he here? \\
\hline
\end{tabular}

One cannot escape the conclusion that this method has been of great help in the translation process. The fact remains, however, that the equivalent effect has not been achieved only by words, but also by the synchronised picture, which puts into doubt the validity of this particular translation technique. Finally, some examples of the neutralisation technique will be considered:

Table 3: Neutralisation

\begin{tabular}{|l|l|l|}
\hline No. & \multicolumn{1}{|c|}{ Polish } & \multicolumn{1}{c|}{ English } \\
\hline 5. & Józka: A chodźże do chałupy. & Józka: Come home. \\
\hline 6 & Maciej: Nie miarkuję, w czym rzecz! & Maciej: What's all about ${ }^{3}$ ? \\
\hline 7. & {$[$ Krowa] graniasta } & The roan one [about a cow] \\
\hline
\end{tabular}

As suggested above, extracting the meaning from the ST and transferring it to the standard TT may be a useful method in AVT. Regretfully, by constructing a coherent TT expression, this solution reduces the ST sound to nearly zero. What is more, one may observe that the term "roan one" is not a valid choice in this regard. The word "graniasta" has been defined by Karłowicz (1900) as a "cattle colour of red patch on white background, or the other way round," whereas the term "roan one" is used generally in reference to the colour of a horse.

\subsection{Translation techniques aimed at TT reduction}

Proceeding to the next set of examples, Table 4 below illustrates the omission technique:

3 This phrase is in fact a non-standard grammatical construction (the standard English variety is "What is it all about?". Consequently, despite its attempt, the instance described here fails to "neutralise" the utterance. 
Table 4: Omission

\begin{tabular}{|c|l|l|}
\hline No. & \multicolumn{1}{|c|}{ Polish } & \multicolumn{1}{|c|}{ English } \\
\hline 8. & Antek: Ja cię sponiewierałem, co? Ja? & Antek: Me? \\
\hline 9. & $\begin{array}{l}\text { Villager: O mościewy! Zasiewów do żniw, } \\
\text { nie każdy będzie żyw! }\end{array}$ & $\begin{array}{l}\text { Villager: While the grass grows, the horse } \\
\text { starves. }\end{array}$ \\
\hline 10. & Witek: Dyć baczę, Kuba, baczę. & Witek: I'm minding. \\
\hline 11. & $\begin{array}{l}\text { Dominikowa: Morowe powietrze was } \\
\text { wydusi, znajdę sprawiedliwość na zbójów! }\end{array}$ & $\begin{array}{l}\text { Dominikowa: I'll bring you justice, you } \\
\text { bandits! }\end{array}$ \\
\hline 12. & $\begin{array}{l}\text { Villager: Piszą, że rzeczy po nim możecie } \\
\text { odebrać u naczelnika w powiecie. }\end{array}$ & $\begin{array}{l}\text { Villager: You can collect the things at the } \\
\text { police station. }\end{array}$ \\
\hline 13. & $\begin{array}{l}\text { Kuba: Oberznijcie wy, oberznijcie!... Co } \\
\text { tylko zechcecie, zapłacę... Do szpitala nie } \\
\text { pójdę, wolę tutaj zdychać... }\end{array}$ & $\begin{array}{l}\text { Kuba: You do it. I'll pay you anything } \\
\text { you say. I'd rather perish here. }\end{array}$ \\
\hline
\end{tabular}

In the examples above, all the insubstantial elements of non-standard speech (respectively: whole sentences, terms of address, interjections, curses, and culture-specific items) have been omitted without harming the general TT message. Needless to say, the procedure of cutting the problematic structures out of the text resulted in deleting the original rustic sound. However, by means of over-excessive use of omission one may produce an incoherent passage. The form of honorifics constructed on the basis of the second person plural (as opposed to the third person singular) used to constitute a widely used method of addressing an unknown person in Polish village talk (Urbańczyk 1984 [1953]: 50). Unfortunately, those peculiar plural addressative forms were neutralized in Example 13. Consequently, the TT blurs the social relationship between the characters. Worse still, the application of the omission technique resulted in harming the semantic structure of the TT. Rather amusingly, it seems that Kuba would rather die in the old shed than be rescued. Next, the table below illustrates the grammar-simplifying approach:

Table 5: Grammar-simplifying techniques

\begin{tabular}{|l|l|l|}
\hline No. & \multicolumn{1}{|c|}{ Polish } & \multicolumn{1}{|c|}{ English } \\
\hline 14. & Maciej: No... mówcie, czego chcecie. & Maciej: So... talk. \\
\hline 15. & Villager: Rzekliście mądre słowo, Macieju! & Villager: You're right. \\
\hline 16. & $\begin{array}{l}\text { Jankiel: Co się Kuba rzuca! Niech Kuba } \\
\text { zapłaci i idzie sobie do diabła! }\end{array}$ & $\begin{array}{l}\text { Jankiel: Don't yell! Pay and go to } \\
\text { hell! }\end{array}$ \\
\hline
\end{tabular}

Example 14, constituting a repetition of the method used in the previous example, ${ }^{4}$ additionally offers an insight into a radical application of the omission technique, which cut out the majority of the original passage. In Example 15, the

4 The character was addressing one person using the previously described rustic plural form. 
volume of words uttered has been significantly reduced. In Example 16, however, the rhyming TT structure may cause an unintentional effect of amusement.

\subsection{Translation techniques aimed at producing the effect of foreignness}

Finally, techniques evoking foreignness will be discussed. Table 6 below illustrates the colloquialisation technique:

Table 6: Colloquialisation

\begin{tabular}{|l|l|l|}
\hline No. & \multicolumn{1}{|c|}{ Polish } & \multicolumn{1}{c|}{ English } \\
\hline 17. & Villager: Co się gospodarz gniewa. & Villager: Cool down. \\
\hline 18. & Dominikowa: Miarkuję, Pietrze, miarkuję! & Dominikowa: I get it, Piotr. \\
\hline
\end{tabular}

This method, although successfully linking the speakers to a lower stratum of society, leaves a lot to be desired. It may be observed that there is almost no correlation between the TT and the language variety understood as "typical" village talk. Last but not least, the strategy of foreignisation through domestication will be examined:

Table 7: Foreignisation through domestication

\begin{tabular}{|c|l|l|}
\hline No. & \multicolumn{1}{|c|}{ Polish } & \multicolumn{1}{|c|}{ English } \\
\hline 19. & $\begin{array}{l}\text { Hanka: Koniecznie naparł się iść do Czę- } \\
\text { stochowy. }\end{array}$ & $\begin{array}{l}\text { Hanka: He insisted on going to pray to } \\
\text { the holy picture. }\end{array}$ \\
\hline 20. & $\begin{array}{l}\text { Józka: Wosk topili, leli jej w gardziel, i nic. } \\
\text { I sól, i nic [...]. Pewnie paskudnik! }\end{array}$ & $\begin{array}{l}\text { Józka: They poured wax in her throat. And } \\
\text { salt. For no good [...]. Must be the Evil } \\
\text { one. }\end{array}$ \\
\hline
\end{tabular}

In Example 19, the name of the greatest Polish Catholic place of worship has been replaced with an adequate explanatory periphrastic substitution. Nonetheless, it does not change the fact that the TT receiver is not acquainted with the phenomenon of a "holy picture" praised by Polish villagers. It can therefore be assumed that the translator's efforts were, in all probability, counterproductive. Finally, "paskudnik" - the term for a cattle disease used in the region of Poznan - has been transferred in a manner which erroneously implies an involvement of the supernatural.

\section{Conclusion}

There were 20 translated phrases to consider, all of them analysed in accordance with the three approaches to AV dialect translation presented above. One may 
observe that the prevailing translation techniques used in The Peasants are those which either aim at assimilating the TT receiver with the ST message (e.g. explanatory periphrastic substitution and neutralisation) or simply cut out the problematic culture-specific items (e.g. omission). On the other hand, there are also instances of foregnised passages. Nevertheless, it is worth noting that no matter what the translator's choice was, the target lexical items were thoroughly deprived of their rustic sound. The mutual exclusion of the AV text maximal condensation rule and an evaluative yet detailed approach to dialect translation resulted in the construction of a smooth TT, which, allowing the audience to focus on the events of the film, simultaneously deprived them of any chance of experiencing the rustic character of the ST. It may be reasonably concluded then that the dual constraint hypothesis is entirely valid. What is more, in the course of the analytical study, a third constraint, namely: the translator's constraint, has been created. The author of the TT is always built into the transfer and, as such, should be considered as a third very important issue conditioning the quality of the TT. This factor, which is constantly operating in the process of translation, cannot be ruled out. It will always influence the TT and may result in various grammatical mistakes (as in Example 6). As observed by Pinto, "it is not difficult to accept that the translated text is also full of the translators' presence as he/she finds him/herself in the difficult position of recreating in the TT communicative meanings constructed in the ST that not only are socio-culturally determined, but also express an ideological structure, which will necessarily know a different outline in the target context" (Pinto 2017: 5). It should be mentioned, however, that the research conducted here does not allow for an exhaustive evaluation of the subject matter. Therefore, this study on AV dialect translation as well as the effectiveness of the translation techniques calls for further examination of the topic.

\section{References}

Bałuk-Ulewiczowa, T. 2000. "Beyond Cognizance: Fields of Absolute Untranslatability.” In: Kubiński, W., O. Kubińska, and T.Z. Wolański (eds.). Przekładając nieprzekładalne. Gdańsk: Wydawnictwo Uniwersytetu Gdańskiego. 173-182.

Belczyk, A. 2007. Tlumaczenie filmów. Wilkowice: Wydawnictwo Dla Szkoły.

Berezowski, L. 1997. Dialect in Translation. Wrocław: Wydawnictwo Uniwersytetu Wrocławskiego.

Brett, D. 2009. "Eye Dialect: Translating the Untranslatable." In: AnnalSS. Lost in Translation. Testi e culture allo specchio. 49-62. http://www.lingue.uniss.it/lingue/annali_file/vol_6/4_Brett_ Lost.pdf.

Brodovich, O. 1997. "Translation Theory and Non-Standard Speech in Fiction.” Perspectives: Studies in Translatology 5:1. 25-31.

Brumme, J. and A. Espunya (eds.). 2012. The Translation of Fictive Dialogue. Amsterdam: Rodopi. Catford, J.C. 1965. A linguistic Theory of Translation. Oxford: Oxford University Press.

Chambers, J.K. and P. Trudgill 2004 [1998]. Dialectology. Cambridge: Cambridge University Press. 
Díaz-Cintas, J. 2003. "Audiovisual Translation in the Third Millennium.” In: Anderman, G. and M. Rogers (eds.). Translation Today. Trends and Perspectives. Clevedon: Multilingual Matters. 192-204.

—. 2004. "In Search of Theoretical Framework for the Study of Audiovisual Traslation." In: Orero, P. (ed.). Topics in Audiovisual Translation. Amsterdam: John Benjamins Publishing Company. 21-34.

Díaz-Cintas, J. and M.F. Cruz 2008. "Using Subtitled Video Materials for Foreign Language Instruction.” In: Díaz-Cintas, J. (ed.). The Didactics of Audiovisual Translation. Amsterdam: John Benjamins Publishing Company. 201-214.

Dudek, A. 2015. The Untranslatability of Dialects into the Language Used in Films: An Analysis of Translation Techniques Used in the English Subtitles to The Peasants [Nieprzekładalność dialektów na język filmowy: analiza technik tłumaczeniowych zastosowanych w angielskich podpisach do filmu The Peasants]. Unpublished MA paper. Wrocław: University of Wrocław.

Eser, O. 2015. "A Model of Translator's Competence from an Educational Perspective." International Journal of Comparative Literature \& Translation Studies 3:1. 4-15.

Francis, W.N. 1987 [1983]. Dialectology. An Introduction. New York: Longman.

Gambier, Y. 2003. "Screen Transadaptation: Perception and Reception." In: Baker, M. (ed.). The Translator. Studies in Intercultural Communication. vol. 1. Manchester: St. Jerome Publishing. 171-189.

Hejwowski, K. 2006. Kognitywno-komunikacyjna teoria przekładu. Warszawa: Wydawnictwo Naukowe PWN.

—. 2015. Iluzja przekładu. Przektadoznawstwo w ujęciu konstruktywnym. Katowice: Śląsk.

Jull Costa, M. 2007. "Mind the Gap: Translating the Untranslatable." In: Anderman, G. (ed.). Voices in Translation, Bridging Cultural Divides. Clevedon: Multilingual Matters Ltd. 111-122.

Karłowicz, J. 1900. Stownik gwar polskich. Kraków: Drukarnia C.K. Uniwersytetu Jagielońskiego. http://zbc.uz.zgora.pl/dlibra/doccontent?id=8866.

Kizeweter, M. 2012. "Kuszenie thumacza, czyli przekładanie jako poprawianie oryginału." In: Hejwowski, K. and A. Szczęsny (eds.). Tłumacz: sługa, pośrednik, twórca? Warszawa: Instytut Lingwistyki Stosowanej. 435-445.

Kuhwiczak, P. 2003. "The Troubled Identity of Literary Translation.” In: Anderman, G. and M. Rogers (eds.). Translation Today. Trends and Perspectives. Clevedon: Multilingual Matters. 112 124.

Lebiedziński, H. 1981. Elementy przekładoznawstwa ogólnego. Warszawa: Wydawnictwo Naukowe PWN.

Lefevere, A. 1977. Translating Literature: The German Tradition from Luther to Rosenzweig. Assen: Van Gorcum.

Lefevere, A. (ed.). 1992. Translation, History, Culture. A Sourcebook. London: Routledge.

Morini, M. 2006. "Norms, Difference, and the Translator: Or, How to Reproduce Double Difference." Review of Literatures of the European Union: Traduzione Tradizione? Paths in the European Literary Polysystem 4. 123-140. http://www.rilune.org/images/mono4/11_Morini. pdf.

Newmark, P. 1988. A Textbook of Translation. London: Prentice Hall.

—. 1991. About Translation. Clevedon: Multilingual Matters.

Nida, E. 2000 [1964]. "Principles of Correspondence." In: Venuti, L. (ed.). The Translation Studies Reader. New York: Routledge. 126-140.

Patterson. C. 2006. "Javier Marias: In Search of Lost Time. Interview with Javier Marias." The Independent. 28 July. https://www.independent.co.uk/arts-entertainment/books/features/javiermarias-in-search-of-lost-time-409503.html. 
Pinto, S.R. 2009. "How Important is the Way You Say It? A Discussion on the Translation of Linguistic Varieties." Target. 289-307. https://translatiostudium.files.wordpress.com/2014/08/ how-important-is-the-way-you-say-it-ramos-pinto.pdf.

- 2016. "Yo Care How Me Speaks, Do Ya? The Translation of Linguistic Varieties and its Reception." inTRAlinea: Online Translation Journal. http://www.academia.edu/34997307/Yo care how_me_speaks_do_ya_The_translation_of_linguistic_varieties_and_its_reception.

—. 2017. "Film, Dialects and Subtitles: An Analytical Framework for the Study of Non-standard Varieties in Subtitling." Translator. https://www.researchgate.net/publication /317591298 Film_dialects_and_subtitles_an_analytical_framework_for_the_study_of_non-standard_varieties_in_subtitling.

Rothe-Neves, R. 2007. "Notes on the Concept of Translator's Competence." Quaderns. Revista de Traducció 14. 125-138.

Schleiermacher, F. 1813. Ueber die verschiedenen methoden des Uebersetzens [On the different methods of translating]. http://users.unimi.it/dililefi/costazza/programmi/2006-07/Schleiermacher.pdf

The Peasants [Chłopi]. Dir. Jan Rybkowski. Polart Video 2006 [Telewizja Polska S.A. 1973].

Toda, F. 2008. "Teaching Audiovisual Translation in a European Context.” In: Díaz-Cintas, J. (ed.). The Didactics of Audiovisual Translation. Amsterdam: John Benjamins Publishing Company. 159-168.

Tomaszkiewicz, T. 2006. Przekład audiowizualny. Warszawa: Wydawnictwo Naukowe PWN.

Urbańczyk, S. 1984 [1953]. Zarys dialektologii polskiej. Warszawa: Wydawnictwo Naukowe PWN. Venuti, L. 1995. The Translator's Invisibility. A History of Translation. London: Routledge.

—. 2000. "Translation, Community, Utopia." In: Venuti, L. (ed.). The Translation Studies Reader. New York: Routledge. 468-488.

Wojtasiewicz, O. 1992 [1957]. Wstęp do teorii ttumaczenia. Warszawa: Zakład im. Ossolińskich-Wydawnictwo Polskiej Akademii Nauk. 